JUSPI: Jurnal Sejarah Peradaban Islam

Vol. 1 No. 2 Tahun 2017

ISSN 2580-8311

\title{
MASJID PATHOK NEGORO MLANGI: RESPON MASYARAKAT MLANGI TERHADAP RENOVASI MASJID TAHUN $2012 \mathrm{M}$
}

\author{
Umi Azizah \\ Progam Studi Sejarah dan Kebudayaan Islam UIN Sunan Kalijaga \\ Yogyakarta \\ Email:azizahumia@gmail.com
}

The mosque is a place of worship of muslim, one of them is to perform the congregational prayers. Mosque Pathok Negoro Mlangi besides being use as a place of prayers congregation is also used as a place of spreading of Islam religion in Mlangi. The status of Mosque Pathok Negoro Mlangi is under the rule of Sultanate Yogyakarta. This mosque is also used as a cultural heritage and classified into cultural heritage buildings protected by UU No 11 in 2010. So, it is not arbitrary people can change the shape of the building. This study aims to determine the response of Mlangi community to renovate Mosque Pathok Negoro Mlangi in 2012. Data collection is done by interview, observation, and documentation, as well as verivication and interpretation to know the source validity. The community's response to the renovation of the mosque in 2012 contradicts each other. Some people who support but not a few who refuse the renovation. The motive for the renovation in 2012 is to restore the characteristics of the mosque building Pathok Negoro Mlangi at the mosque Kagungan Dalem which has been lost due to renovations made in 1985 by Mlangi community.

Key Word: Mosque Pathok Negoro Mlangi, Society Mlangi, Renovation

Masjid merupakan tempat beribadah umat Islam, salah satunya untuk menjalankan sholat berjamaah. Masjid Pathok Negoro Mlangi selain digunakan sebagai tempat sholat berjamaah, juga digunakan sebagai pusat penyebaran agama Islam di Mlangi. Status Masjid Pathok Negoro Mlangi berada di bawah naungan Kesultanan Yogyakarta. Masjid ini juga dijadikan sebagai warisan budaya dan digolongkan kedalam bangunan cagar budaya yang dilindungi dengan UU No 11 Tahun 2010. Sehingga tidak sembarangan orang bisa mengubah bentuk bangunan tersebut. Penelitian ini bertujuan untuk mengetahui respon masyarakat Mlangi terhadap renovasi Masjid Pathok Negoro Mlangi pada tahun 2012. Pengumpulan data dilakukan dengan wawancara, observasi, dan dokumentasi serta melakukan verifikasi dan interpretasi untuk mengetahui keabsahan sumber. Respon masyarakat Mlangi terhadap renovasi masjid yang dilakukan pada tahun 2012 saling bertentangan. Sebagian masyarakat banyak yang mendukung dan ada juga yang menolak renovasi dilakukan. Motif dilakukannya renovasi pada tahun 2012 adalah, untuk mengembalikan ciri khas bangunan Masjid Pathok Negoro Mlangi sebagai masjid Kagungan Dalem yang telah hilang akibat renovasi yang dilakukan pada tahun 1985 oleh masyarakat Mlangi.

Kata kunci: Masjid Pathok Negoro, Masyarakat Mlangi, Renovasi

\section{PENDAHULUAN}

Daerah Istimewa Yogyakarta merupakan salah satu daerah istimewa di Indonesia yang terus mengalami perkembangan dalam berbagai bidang. Kota ini telah menjadi tempat berbagai golongan masyarakat berinteraksi dalam kehidupan sehari-hari. Berbagai agama di kota ini bebas dianut, hal ini dapat dibuktikan dengan banyaknya tempat-tempat ibadah seperti gereja 
JUSPI: Jurnal Sejarah Peradaban Islam

Vol. 1 No. 2 Tahun 2017 ISSN 2580-8311

dan masjid. Masjid sangat identik dengan umat muslim, dan mayoritas masyarakat Yogyakarta menganut agama Islam. Dalam wilayah Yogyakarta banyak berdiri masjid baik masjid kagungan dalem maupun masjid milik masyarakat Yogyakarta. Salah satu masjid kagungan dalem yang masih eksis hingga sekarang adalah Masjid Pathok Negoro.

Sebutan Pathok Negoro yang melekat pada Masjid Pathok Negoro sebenarnya mengikuti sebuah jabatan abdi dalem keraton yang ditugaskan untuk membantu tugas penghulu hakim. Abdi dalem tersebut di tempatkan di empat Masjid Pathok Negoro yaitu Masjid Ploso Kuning, Masjid Babadan, Masjid Dongkelan, dan Masjid Mlangi (Lihat S,Ilmi Albiladiyah: 1993). Pathok Negoro menjadi alat yang sangat penting bagi keraton untuk tetap bisa mengambil kontrol terhadap batas-batas spiritual keraton. Pathok Negoro mampu merefleksikan diri sebagai cerminan watak dan karakter keraton karena posisinya sebagai hasil karya cipta keraton. Hal ini yang memunculkan pemahaman bahwa karakter yang dimiliki pathok negoro adalah karakter yang dimiliki oleh keraton (Yenny Retno, 2015:6-7). Dengan demikian Masjid Pathok Negoro di bangun sebagai hasil karya cipta keraton.

Sebagai hasil karya cipta keraton, arsitektur Masjid Pathok Negoro juga memiliki karakteristik lebih dibandingkan dengan masjid yang lainnya. Indri Rahmawati dalam tesisnya yang berjudul "Arsitektur Masjid Pathok Negoro Ditinjau dari Fungsi, Bentuk, Ruang, dan Teknik" menuliskan bahwa Masjid Pathok Negoro memiliki karakteristik keletakan. Karakteristik tersebut merupakan konsep awal pendirian yang terpengaruh oleh keadaan sosial masyarakat Yogyakarta. Karakteristik yang terdapat pada Masjid Pathok Negoro secara perlahan berubah dari yang senyatanya, seiring berkembangnya kebutuhan masyarakat dimana masjid tersebut didirikan. Yenny Retno Mallany dalam penelitiannya tentang Pathok Negoro Menghadapi Perubahan Zaman, membuktikan bahwa empat titik Pathok Negoro yang dibangun atas dasar tujuan, historis, bahkan identitas yang sama yang telah diberikan keraton tetapi kini memperlihatkan karakter yang berbeda. Mlangi dan Plosokuning masih berusaha mempertahankan identitasnya sebagai Pathok Negoro. Sedangkan Dongkelan dan Babadan tidak mampu mempertahankan identitasnya sebagai Pathok Negoro.

Identitas Masjid Pathok Negoro yang dapat dilihat secara langsung adalah segi arsitekturnya. Sebagai hasil karya cipta keraton, bentuk fisik Masjid Pathok Negoro mengikuti budaya keraton, yaitu arsitektur Jawa Kuno. Ciri khas pada bangunan Masjid Pathok Negoro diantaranya adalah, terdapat empat saka guru di ruang utama, yang terbuat dari kayu. Serambi masjid dikelilingi dengan kolam dan atap masjid bertumpang dua. Ketiga ciri 
JUSPI: Jurnal Sejarah Peradaban Islam

Vol. 1 No. 2 Tahun 2017

ISSN 2580-8311

khas tersebut tidak bisa dipisahkan dari bangunan Masjid Pathok Negoro sebagai masjid Kagungan Dalem (Hasil wawancara dengan GBPH Yudhaningrat, salah satu keluarga Keraton Yogyakarta dan Kepala DISBUD pada tahun 2012, dikediamannya pada 7 Januari 2017 ). Sebagai masjid yang memiliki nilai historis yang tinggi, Masjid Pathok Negoro dijadikan sebagai warisan budaya dan telah digolongkan menjadi bangunan cagar budaya yang dilindungi dengan Undang-Undang (UU) No 11 Tahun 2010 Tentang Cagar Budaya. Adanya UU tersebut, maka tidak sembarang orang bisa mengubah bentuk bangunan tanpa seijin pihak yang berwenang.

Pada tahun 1985 masyarakat Mlangi merenovasi Masjid Pathok Negoro Mlangi menjadi bangunan masjid yang berarsitektur modern. Renovasi tersebut telah menghilangkan ciri khas yang terdapat pada arsitektur Masjid Pathok Negoro. Ditetapkannya UU No 11 Tahun 2010 membawa Sultan Hamengku Buwono $X$ untuk kembali menginstruksikan para pengurus masjid guna mengembalikan bangunan masjid ke bentuk asalnya (Hasil wawancara dengan M Aban Ichwan, ta'mir Masjid Pathok Negoro Mlangi dan andil dalam renovasi tahun 2012 dikediamannya pada tanggal 16 November 2016). Instruksi Sultan telah menuai pro dan kontra dalam masyarakat Mlangi, sehingga renovasi baru bisa dilaksanakan pada tahun 2012.

Berdasarkan permasalahan di atas, penulis terdorong untuk mengkaji lebih dalam mengenai respon masyarakat Mlangi terhadap renovasi masjid pada tahun 2012. Peristiwa ini belum diekspos lebih dalam oleh media masa, bahkan banyak pengunjung yang tidak mengetahui bahwa bangunan masjid yang berdiri sekarang adalah bangunan hasil renovasi pada tahun 2012. Sehingga penulis merasa kajian ini penting untuk dilakukan guna menambah wawasan mengenai perkembangan Masjid Pathok Negoro Mlangi dalam Kesultanan Yogyakarta.

Penelitian ini merupakan penelitian sejarah dan bersifat studi lapangan, sehingga dalam pelaksanaannya penulis melakukan beberapa tahapan diantaranya heuristik, verifikasi, interpretasi, dan historiografi (Dudung Abdurrahman, 2011:126). Dalam pengumpulan sumber penulis melakukan observasi secara langsung dengan mendatangi lokasi masjid dan melakukan wawancara secara langsung dengan pihak-pihak yang berhubungan dengan peristiwa tersebut. Selain hal tersebut penulis juga mengumpulkan arsip yang berupa foto mulai dari prosesi musyawarah pihak keraton dengan masyarakat hingga proses renovasi tahun 2012 berlangsung. Arsip-arsip tersebut penulis dapatkan dari DISBUD Kota Yogyakarta dan Perpustakaan Keraton Yogyakarta. 


\section{PEMBAHASAN}

\section{Masjid Pathok Negoro Mlangi Sebelum Renovasi Tahun 2012}

Secara geografis Masjid Pathok Negoro Mlangi terletak di Desa Mlangi, Kelurahan Nogotirto, Kecamatan Gamping, Kabupaten Sleman. Letak masjid ini berada di sebelah barat laut Keraton Yogyakarta dengan jarak $7 \mathrm{~km}$. Masjid Pathok Negoro Mlangi terletak di Desa Mlangi. Pada saat di dirikan, luas bangunan masjid $286 \mathrm{~m}^{2}$, akan tetapi ketika dilakukan pengembangan pada tahun 1985 luasnya menjadi $400 \mathrm{~m}^{2}$. Masjid Pathok Negoro Mlangi berdiri diatas sebidang tanah kesultanan yang luasnya mencapai $1.000 \mathrm{~m}^{2}$. Luas bagian utama $20 \times 20 \mathrm{~m}^{2}$, serambi masjid $12 \times 20 \mathrm{~m}^{2}$, dan halaman masjid seluas $500 \mathrm{~m}^{2}$. Di masjid ini juga terdapat tempat untuk berwudhu yang terdiri dari dua buah, satu untuk laki-laki dan satu untuk perempuan (Ngatidjan dkk, 2007: 86).

Masjid Pathok Negoro Mlangi adalah Masjid Pathok Negoro yang pertama kali didirikan dari Masjid Pathok Negoro yang lain. Masjid ini didirikan pada tahun $1755 \mathrm{M}$ sebagai masjid yang berada di bawah naungan Kesultanan Keraton Yogyakarta. Masjid Pathok Negoro secara umum tidak hanya digunakan sebagai tempat beribadah dan penyebaran Agama Islam, akan tetapi masjid-masjid tersebut juga berfungsi sebagai tiang negara, keamanan dan batas wilayah, serta sebagai pertahanan rakyat. Masjid Pathok Negoro Mlangi diserahkan kepada Kyai Nur Iman. Kyai Nur Iman memiliki nama asli Raden Mas Sandeyo, ia merupakan saudara Sultan Hamengkubuwono I (Arsip silsilah Kyai Nur Iman). Kyai Nur Iman menjadikan Masjid Pathok Negoro Mlangi sebagai tempat sholat, penyebaran ilmu-ilmu keagamaan yang beraliran ahli al-sunnah wa al-jama'ah, penguatan kebudayaan keraton, pengadilan surambi, dan penanaman jiwa patriotisme kepada kader-kader kemerdekaan pada saat itu. Sebelum renovasi pada tahun 1985 dilakukan, keadaan Masjid Pathok Negoro Mlangi baik dari segi bangunan maupun kondisi sekitar masjid tidak begitu memadai sebagai tempat untuk beribadah. Sesuai wawancara dengan GBPH Yudhaningrat menjelaskan sebagai berikut:

“... Dari dulu memang keadaan masjid gak begitu bagus, dindingnya cuma dilepa pakai lendut (tanah lumpur), ya kumuh gitu lah, trus kayu-kayunya juga sudah pada kropos"

Pada tahun 1985 jama'ah Masjid Pathok Negoro Mlangi semakin banyak, sehingga membutuhkan ruangan masjid yang luas untuk menampung para jama'ah terlebih ketika melaksanakan sholat Jumat. 
Konsep awal renovasi masjid pada tahun 1985, hanya memperluas bangunan masjid. Karena tuntutan untuk kebutuhan masyarakat, bangunan masjid kemudian ditambah satu lantai. Sehingga Masjid Pathok Negoro Mlangi menjadi masjid dengan bangunan berlantai dua. Untuk mempertahankan identitas masjid sebagai salah satu Masjid Pathok Negoro, atap utama masjid dipertahankan dan ditinggikan lebih tinggi dari sebelumnya. Renovasi pada tahun 1985, telah mengubah konstruksi bangunan dengan pilar-pilar beton. Pada renovasi ini menambahkan masjid dengan menara yang berdiri kokoh disisi depan sebelah utara masjid. Kolam yang terdapat disekeliling masjid juga dihilangkan (Dokumentasi dari DISBUD Yogyakarta).

\section{Renovasi Masjid Pathok Negoro Mlangi Pada Tahun 2012}

Renovasi yang dilakukan pada tahun 2012 adalah renovasi yang mendapatkan perintah langsung dari Sultan Hamengku Buwono IX dan berlangsung hingga kepemimpinan Sultan Hamengku Buwono X. Renovasi tersebut dilakukan untuk mengembalikan bangunan masjid yang telah di renovasi oleh masyarakat Mlangi pada tahun 1985. Hasil renovasi pada tahun 1985 telah menghilangkan bentuk asli bangunan Masjid Pathok Negoro Mlangi. Sehingga, karakter utama yang dimiliki Masjid Pathok Negoro telah hilang. Inilah yang menjadi motif Sultan untuk mengembalikan bangunan Masjid Pathok Negoro Mlangi kebentuk asalnya.

Renovasi pada tahun 2012 dimulai dengan pemugaran atap utama masjid dengan pilar-pilar beton yang menopang atap. Dinding yang mengitari ruang utama masjid tetap dipertahankan. Kemudian melakukan pemilihan konstruksi-konstruksi bangunan masjid seperti tiang, kayu dan genteng. Dalam pemilihan konstruksi-konstruksi tersebut, dilakukan dengan kesepakatan antara pihak keraton dengan pengurus masjid (Hasil wawancara dengan GBPH Yudhaningrat dan M. Aban Ichwan). Setelah memilih konstruksi bangunan yang dibutuhkan sesuai kesepakatan bersama, renovasi masjid mulai dilakukan. Renovasi Masjid Pathok Negoro Mlangi pada tahun 2012 dilakukan dengan tiga tahap, yaitu tahap satu bagian utama masjid, tahap kedua bagian serambi masjid, dan tahap ketiga bagian luar masjid.

Tahap pertama dimulai pada bulan Juni tahun 2012, atap masjid yang semula ditinggikan kemudian diturunkan. Penyangga atap yang terbuat dari beton semua dihancurkan. Hanya dinding yang mengitari ruang utama masjid yang masih dipertahankan. Konstruksi dinding yang dipertahankan hanya batu bata, sedangkan lapisan semen yang melapisi batu bata dihancurkan dan diganti dengan adonan semen yang baru. Selain itu, jendela 
dan pintu yang terdapat pada ruang utama masjid diganti dengan kayu. Sebelum empat saka guru didirikan, terlebih dahulu atap serambi masjid dihancurkan. Hal itu dilakukan untuk mempermudah pemasangan atap utama masjid. Setelah dinding selesai diperbaiki, pada bulan Oktober 2012 empat saka guru utama yang terdapat diruang utama masjid mulai didirikan. Tepat pada tanggal 20 November 2012 ruang utama masjid sudah terselesaikan (Dokumentasi dari DISBUD Yogyakarta).

Setelah ruang utama masjid terselesaikan, dilanjutkan pada tahap kedua yaitu bagian serambi masjid. Pada tahap kedua, terlebih dahulu renovasi dilakukan dengan merobohkan seluruh konstruksi serambi masjid. Hampir seluruh konstruksi pada serambi masjid tidak ada yang dipertahankan, termasuk dinding dan atap serambi masjid. Dinding yang mengitari sebelah kanan dan kiri serambi masjid kemudian dirobohkan dan dihilangkan. Saat ini serambi masjid menjadi ruangan terbuka, dinding yang tadinya terdapat disebelah sisi kanan dan kiri serambi digantikan dengan pagar kayu yang tingginya hampir mencapai 1,5 m. Atap serambi masjid yang sebelumnya tidak bergenteng dan berbentuk datar, kemudian diganti dengan genteng dan berbentuk limasan. Tiang-tiang penyangga atap diganti dengan kayu. Tiang-tiang tersebut berdiri diatas umpak berwarna hitam yang terbuat dari batu. Saat ini tiang penyangga atap serambi masjid terdiri dari delapan tiang. Sebelumnya tiang-tiang pada serambi masjid menggunakan pilar-pilar dari beton yang dilapisi dengan semen kemudian dicat dengan warna biru muda. Tangga yang sebelumnya terdapat di sebelah kanan dan kiri serambi masjid juga dihilangkan. Tangga tersebut sebelumnya berfungsi sebagai jalan untuk menuju ruangan masjid yang terdapat dilantai dua.

Tahap ketiga renovasi pada halaman masjid, yang terdiri dari kolam dan bangsal. Kolam yang tadinya dihilangkan kini dikembalikan dengan kedalaman hampir mencapai $4 \mathrm{~m}$. Kolam ini kemudian digunakan untuk ternak ikan sekaligus untuk tempat bersuci ketika akan memasuki masjid. Dengan adanya kolam ini, para jamaah yang akan memasuki serambi masjid keadaan kakinya telah bersih dari najis. Dinding kolam dibangun dengan batu bata yang dilapisi semen kemudian dicat dengan warna biru tua dan bagian atas berwarna putih. Disebelah ujung kanan kolam terdapat tangga menurun yang terdapat didalam kolam. Tangga tersebut berfungsi sebagai jalan untuk kedalam kolam ketika akan membersihkan kolam.

Setelah mengembalikan kolam yang terdapat disekeliling masjid, Sultan meminta untuk menambahkan bangsal di depan masjid. Bangsal dibangun di sisi kanan dan kiri halaman masjid. Bangsal ini dibangun 
layaknya bangunan pendopo pada umumnya, hanya saja bangsal tersebut tidak dikelilingi oleh dinding melainkan dikelilingi dengan pagar kayu yang tingginya hampir mencapai satu meter. Konstruksi bangunan bangsal mirip dengan konstruksi bangunan serambi masjid. Hanya saja bangsal berdiri diatas basement yang kedalamannya hampir mencapai tujuh meter. Atap bangsal berbentuk limasan sama dengan atap serambi masjid. Atap bangsal disangga dengan delapan tiang yang terbuat dari kayu dengan umpak yang berwarna hitam.

\section{Respon Masyarakat Mlangi Terhadap Renovasi Masjid Pada Tahun 2012}

Suatu tingkatan hidup serta penghidupan masing-masing manusia berbeda-beda. Dalam masyarakat terdapat suatu tingkatan atau golongangolongan yang membedakan status antara masing-masing warga. Golongangolongan tersebut diantaranya adalah, golongan tinggi, golongan sedang, dan golongan rendah. Dalam hal ini golongan rendah layaknya golongan orang-orang miskin (M. Cholil Mansur, 2007: 156). Berbeda dengan sistem golongan di masyarakat Mlangi, yaitu Mlangi njero dan Mlangi njobo. Golongan rendah tidak jauh berbeda dengan golongan biasa, yang biasanya sebagai orang-orang bawah yang dianggap miskin. Dalam Masyarakat Mlangi golongan biasa tidak memandang dia kaya atau miskin. Meskipun sebagai pejabat dan berdomisili di Mlangi serta bukan dari keturunan Kyai Nur Iman, mereka tetap golongan Mlangi njobo.

Dalam lingkungan Masjid Pathok Negoro secara umum, masih terdapat pola lingkar dalam dan pola lingkar luar. Lingkar dalam adalah tempat untuk pengikut Sultan asli yaitu keturunan asli keluarga keraton. Sedangkan lingkar luar diasosiasikan dengan sekelompok masyarakat yang telah ada sebelum kedatangan Sultan dan diibaratkan sebagai kelompok yang belum berilmu (Lihat Mallany:28-30). Pola tersebut masih terjaga di wilayah Masjid Pathok Negoro Mlangi hingga saat ini yaitu Mlangi njero dan Mlangi njobo. Sebutan Mlangi njero diperuntukan bagi keturunan asli Kyai Nur Iman. Mereka biasanya para tokoh kyai dan pemimpin pondok pesantren di Mlangi. Kebanyakan mereka tinggal di sekitar komplek Masjid Pathok Negoro Mlangi. Sebagai keturunan Kyai Nur Iman mereka beranggapan bahwa di dalam diri mereka terdapat darah keluarga Keraton. Menjadi keturunan Kyai Nur Iman adalah kebanggaan tersendiri bagi warga Mlangi njero. Sebutan Mlangi njobo diperuntukan bagi warga Mlangi yang tidak memiliki darah keturunan Kyai Nur Iman. Kebanyakan mereka adalah warga pendatang, baik santri maupun warga pendatang yang berdomisili tetap di Mlangi (Hasil wawancara dengan Kyai Mustangin, Imam Masjid 
JUSPI: Jurnal Sejarah Peradaban Islam

Vol. 1 No. 2 Tahun 2017

ISSN 2580-8311

Pathok Negoro Mlangi dan salah satu keturunan Kyai Nur Iman pada 13 Desember 2016).

Dua golongan tersebut, terdapat perbedaan pandangan dalam merespon renovasi Masjid Pathok Negoro Mlangi yang dilaksanakan pada tahun 2012. Dalam golongan tokoh agama terdapat dua kubu, yaitu kubu kyai yang pro dan kubu kyai yang kontra terhadap instruksi Sultan. Kubu kyai yang pro tidak bisa menolak perintah Sultan untuk melakukan renovasi masjid guna mengembalikan bentuk bangunan asal masjid. Kubu kyai yang kontra hanya terdiri dari beberapa orang kyai saja. Bagi mereka, merenovasi Masjid Pathok Negoro Mlangi untuk mengembalikan bangunan masjid kebentuk asalnya adalah hal yang tidak mungkin untuk mereka lakukan. Berbagai pertentanganpun dilakukan oleh Kyai yang kontra, dalam menolak renovasi Masjid Pathok Negoro Mlangi kebentuk asalnya pada tahun 2012. Telah disebutkan pada bab sebelumnya, bahwa terdapat dua kyai yang menetang renovasi Masjid Pathok Negoro mlangi kebentuk asalnya. Keduanya sangat menyayangkan bangunan masjid yang telah direnovasi pada tahun 1985 dikembalikan kebentuk asalnya dengan ruangan yang lebih sempit. Selain hal itu, keduanya juga menyayangkan harta bendanya yang telah disedekahkan untuk merenovasi masjid pada tahun 1985 akan sia-sia. Mereka merasa jika masjid direnovasi kebentuk asalnya, maka ada kekawatiran amal mereka akan hilang.

Masyarakat biasa secara umum adalah orang-orang yang tidak memiliki peran penting secara khusus dalam suatu masyarakat. Golongan masyarakat biasa di Mlangi kebanyakan adalah warga pendatang baik santri maupun warga luar Mlangi yang berdomisili di Mlangi. Sebagai warga pendatang tentunya banyak hal yang tidak diketahui tentang Mlangi secara khusus, salah satunya tentang Masjid Pathok Negoro Mlangi. Ketidaktahuan tersebut membawa dampak negatif ketika renovasi Masjid Pathok Negoro Mlangi pada tahun 2012 dilakukan. Golongan masyarakat biasa secara umum tidak menyetujui renovasi Masjid Pathok Negoro ke bentuk asalnya. Alasan mereka tidak jauh berbeda dengan para kyai yang kontra terhadap renovasi Masjid Pathok Negoro Mlangi pada tahun 2012.

Respon masyarakat Mlangi yang kontra terhadap renovasi Masjid Pathok Negoro Mlangi tidak datang dengan sendirinya. Respon tersebut ada yang terbawa omongan tokoh kyai yang kontra dengan renovasi Masjid Pathok Negoro Mlangi pada tahun 2012, ada juga yang memang dari dirinya sendiri. Sudah menjadi tradisi bagi Masyarakat Mlangi, bahwa kyai adalah seorang yang sangat berpengaruh dan berada pada strata tingkat atas. Kyai merupakan sebutan bagi seorang yang 'alim dalam bidang agama Islam. 
Seorang tokoh kyai bagi masyarakat memiliki otoritas karismatik dalam dirinya, hal ini disebabkan karena tingginya ilmu yang dimilikinya dan sebagai waratsatul anbiya', sebagai pewaris para Nabi (Lihat Mallany: 109).

Sejak dahulu, di Mlangi kata "kyai" tidak hanya sebutan semata. Akan tetapi sebuah modal simbolik yang cukup berpengaruh pada ranah-ranah tertentu. Posisi kyai bagi masyarakat Mlangi berada pada lapisan sosial yang sangat penting. Kyai berada pada lapisan elit, terlebih jika ia merupakan bagian dari keturunan asli Kyai Nur Iman. Dalam hal ini, usia juga menjadi hal penting bagi masyarakat Mlangi, kyai dengan usia paling tua maka ia menjadi kyai yang paling dikedepankan. Sudah menjadi kesepakatan umum bagi masyarakat Mlangi bahwa kyai lebih diikuti oleh masyarakat dibanding dengan pegawai pemerintahan atau pemimpin desa. Namum, faktanya para kyai menerima instruksi Sultan sedangkan Sultan bukan golongan kyai di Mlangi melainkan pemimpin kota yang masuk kedalam jajaran pemerintahan.

\section{Dampak Renovasi Masjid Pada Tahun 2012}

Terlepas dari permasalahan diatas renovasi Masjid Pathok Negoro Mlangi kebentuk asalnya pada tahun 2012, telah memberikan dampak positif dan negativ. Dikembalikannya Masjid Pathok Negoro Mlangi kebentuk bangunan asalnya telah mengembalikan nuansa budaya tradisional didalam komplek Masjid Pathok Negoro Mlangi, terutama ciri khas arsitektur tradisionalnya. Hal ini disebabkan model bangunan masjid dikembalikan ke bentuk asalnya, meskipun sebelumnya tidak terdapat dua buah bangsal disisi kanan dan kiri halaman masjid. Ciri-ciri tradisional yang terdapat pada bangunan Masjid Pathok Negoro Mlangi kembali terlihat sebagai masjid Kagungan dalem dengan budaya arsitektur tradisionalnya. Dengan dikembalikannya Masjid Pathok Negoro Mlangi kebentuk asalnya, status Masjid Pathok Negoro Mlangi sebagai masjid kagungan dalem semakin kuat. Sehingga tidak sembarang orang bisa merenovasi dengan asal-asalan dan memiliki masjid secara utuh.

Disisi lain, Setelah dilakukan renovasi pada tahun 2012 ruangan Masjid Pathok Negoro Mlangi lebih sempit dari sebelumnya. Perbedaan sangat terlihat baik dari segi material bangunan maupun ruangannya. Dari segi material bangunan, renovasi yang dilakukan pada tahun 1985 menjadikan tiang-tiang masjid menggunakan beton, termasuk saka guru. Sedangkan renovasi pada tahun 2012, seluruh konstruksi bangunan masjid menggunakan kayu, kecuali dinding masjid yang menggunakan tembok. Jika sebelumnya berlantai dua dengan ruangan yang luas, setelah renovasi pada 
tahun 2012 hanya satu lantai dengan ruangan yang lebih sempit dari sebelumnya. Meskipun demikian, hasil renovasi pada tahun 2012 bisa menampung jamaah meski jumlahnya lebih sedikit dari sebelumnya.

\section{KESIMPULAN}

Hasil penelitian menunjukan bahwa, renovasi pada tahun 2012 telah menuai banyak pro dan kontra dikalangan masyarakat. Dalam golongan tokoh agama, mayoritas para kyai mempersilakan renovasi masjid kebentuk asalnya. Akan tetapi beberapa kyai tidak menyetujui renovasi tersebut. Dalam golongan masyarakat biasa mayoritas masyarakat tidak menyetujui renovasi tersebut dan sebagian masyarakat biasa yang menerimanya. Tokoh agama yang kontra terhadap instruksi Sultan menyadari bahwa Masjid Pathok Negoro Mlangi adalah masjid kagungan dalem. Mereka juga menyadari bahwa penyerahan masjid kepada masyarakat hanya sebatas penyerahan pengelolaan masjid, akan tetapi mereka menyayangkan bangunan masjid yang telah direnovasi pada tahun 1985 oleh masyarakat Mlangi. Meskipun dalam golongan tokoh agama terdapat respon yang berbeda terhadap instruksi Sultan, permasalahan ini tidak menyebabkan perselisihan diantara para kyai di Mlangi. Hubungan mereka tetap harmonis, sebagaimana sebelum adanya permasalahan tentang renovasi Masjid Pathok Negoro Mlangi pada tahun 2012.

\section{Saran}

Mempelajari tentang cagar budaya ataupun bangunan bersejarah merupakan hal penting. Hal ini supaya kita mengerti apa saja yang perlu kita lakukan dan apa saja yang tidak perlu kita lakukan terhadap bangunan yang memiliki status cagar budaya. 


\section{DAFTAR PUSTAKA}

Abdullah, Taufik. Islam dan Masyarakat: Pantulan Sejarah Indonesia. Jakarta: LP3ES. 1987.

Abdurrahman, Dudung. Metodologi Penelitian Sejarah Islam. Yogyakarta: Ombak. 2011.

Albiladiyah, S.Ilmi. Pathok Negoro Sebuah Bentuk Benteng Hukum Pada Abad 18 di Yogyakarta. Yogyakarta: Balai Kajian Sejarah dan Nilai Tradisional. 1993.

Barkoro, Haryadi. Catatan Perjalanan Keistimewaan Yogyakarta: Menurut Sejarah Mencermati Perubahan Menggagas Masa Depan. Yogyakarta: Pustaka Pelajar. 2010.

Basri. Metodologi Penelitian Sejarah: Pendekatan, Teori, Dan Praktik. Jakarta: Restu Agung. 2006.

Handryant, Asyah Nur. Masjid Sebagai Pusat Pengembangan Masyarakat: Integrasi Konsep Hablumminallah, Hablumminannas, \& Hablumminal'alam. Malang: UIN Maliki Press. 2010.

Harun, M Yahya. Kerajaan Islam Nusantara Abad XVI \& XVII. Yogyakarta: Kurnia Alam Sejahtera. 1995.

Mallany, Yenny Retno. Pathok Negoro Menghadapi Perubahan Zaman. Yogyakarta: PolGov. 2015.

Mansyur, M. Cholil. Sosiologi Masyarakat Kota Dan Desa. Surabaya: Usana Offset Printing. 2007.

Ngatidjan dkk. Masjid Bersejarah Provinsi Daerah Istimewa Yogyakarta. Yogyakarta: Kanwil Depag DIY. 2007.

Sumalyo, Yulianto. Arsitektur Mesjid Dan Monumen Sejarah Muslim. Yogyakarta: Gadjah Mada University Press, 2006.

Arsip Silsilah Keturunan Kyai Nur Iman Mlangi Nogotirto Sleman Jogyakarta.

Dokumentasi Renovasi Masjid Pathok Negoro Mlangi. Yogyakarta: Dinas Kebudayaan. 2012.

Rahmawati, Indri. "Arsitektur Masjid Pathok Negoro Ditinjau dari Fungsi, Bentuk, Ruang, dan Teknik”. Yogyakarta: Skripsi Universitas Gajah Mada. 2014. 